\title{
Microbiology and atmospheric processes: chemical interactions of primary biological aerosols
}

\author{
L. Deguillaume ${ }^{1}$, M. Leriche ${ }^{2}$, P. Amato ${ }^{1,3}$, P. A. Ariya ${ }^{4}$, A.-M. Delort ${ }^{3}$, U. Pöschl ${ }^{5}$, N. Chaumerliac ${ }^{1}$, H. Bauer ${ }^{6}$, \\ A. I. Flossmann ${ }^{1}$, and C. E. Morris ${ }^{7}$ \\ ${ }^{1}$ Laboratoire de Météorologie Physique, 24 av. des Landais, 63177 Aubière, France \\ ${ }^{2}$ Laboratoire d'Aérologie, 14 avenue Edouard Belin, 31400 Toulouse, France \\ ${ }^{3}$ Laboratoire Synthèse Et Etude de Systèmes à Intérêt Biologique, 24 av. des Landais, 63177 Aubière, France \\ ${ }^{4}$ McGill University, Departments of Chemistry and Atmospheric and Oceanic Sciences Montreal, 801 Sherbrooke St. W. \\ Montreal, QC, Canada \\ ${ }^{5}$ Max Planck Institute for Chemistry, Biogeochemistry Department, 55128 Mainz, Germany \\ ${ }^{6}$ Inst. for Chemical Technologies and Analytics, Vienna University of Technology, Getreidemarkt 9/164-AC, Vienna, Austria \\ ${ }^{7}$ INRA, Unité de Pathologie Végétale UR407, 84140 Montfavet, France
}

Received: 28 November 2007 - Published in Biogeosciences Discuss.: 15 February 2008

Revised: 4 June 2008 - Accepted: 26 June 2008 - Published: 30 July 2008

\begin{abstract}
This paper discusses the influence of primary biological aerosols (PBA) on atmospheric chemistry and vice versa through microbiological and chemical properties and processes. Several studies have shown that PBA represent a significant fraction of air particulate matter and hence affect the microstructure and water uptake of aerosol particles. Moreover, airborne micro-organisms, namely fungal spores and bacteria, can transform chemical constituents of the atmosphere by metabolic activity. Recent studies have emphasized the viability of bacteria and metabolic degradation of organic substances in cloud water. On the other hand, the viability and metabolic activity of airborne micro-organisms depend strongly on physical and chemical atmospheric parameters such as temperature, pressure, radiation, $\mathrm{pH}$ value and nutrient concentrations. In spite of recent advances, however, our knowledge of the microbiological and chemical interactions of PBA in the atmosphere is rather limited. Further targeted investigations combining laboratory experiments, field measurements, and modelling studies will be required to characterize the chemical feedbacks, microbiological activities at the air/snow/water interface supplied to the atmosphere.
\end{abstract}

Correspondence to: L. Deguillaume (L.Deguillaume@opgc.univbpclermont.fr)

\section{Introduction}

Primary biological aerosols (PBA) are a part of the organic carbon fraction $(\mathrm{OC})$ of carbonaceous aerosols, which with black (BC) or elemental carbon (EC), account for a large fraction of air particulate matter. These carbonaceous aerosols exhibit a wide range of molecular structures, and have a major influence on the physico-chemical, biological, climate- and health-related behaviours of atmospheric aerosols (Seinfeld and Pandis, 1998; Jacobson et al., 2000; Turpin and Saxena, 2000; Seinfeld and Pankow, 2003; Kanakidou et al., 2005; Pöschl, 2005; Fuzzi et al., 2006; and references therein). The origin of BC and EC is mostly pyrogenic (e.g., fossil fuel combustion, biomass burning, Szidat et al., 2004.). The OC is a complex mixture of thousands of organic compounds. The characterisation, classification, and description of the OC in atmospheric models is a major challenge of current atmospheric and climate research (Kanakidou et al., 2005; Fuzzi et al., 2006; Kalberer et al., 2006; Donahue et al., 2006).

PBA are ubiquitous in the atmosphere (Gregory, 1961). They can be viable organisms capable of metabolic reactions which can involve atmospheric organic compounds and oxidants (airborne micro-organisms) (Ariya and Amyot, 2004; Sun and Ariya, 2006). They also comprise either biological particles including alive, dead cells and cell fragments, capable of nucleating cloud droplets and ice particles via physical processes (Möhler et al., 2007; this issue) or any kind of organic substances deriving from biomolecules and

Published by Copernicus Publications on behalf of the European Geosciences Union. 
contributing to aerosol masses. Their presence and dispersion have long been identified in the atmosphere (Gregory, 1971; Edmonds, 1979) and some research has been focused on health hazards (Jones and Cookson, 1983). Several studies have shown that PBA like bacteria, fungal spores, pollen and plant fragments undergo long-range vertical and horizontal transport, and can influence atmospheric chemistry, physics and climate (Wainwright et al., 2003; Griffin et al., 2004; Prospero et al., 2005; Lohmann and Feichter, 2005; Keene and Galloway, 1988; Vali, 1996; Acker et al., 2002; Kanakidou et al., 2005; McFiggans et al., 2006; Fuzzi et al., 2006; Després et al., 2007; Elbert et al., 2007; Möhler et al., 2007; Morris et al., 2008 and references therein).

Recent studies also emphasize the role of bacteria present in polar or mountain environments on the chemistry of such cold environments (Skidmore et al., 2000; Toom-Sauntry and Barrie, 2002; Amato et al., 2007b; Ariya et al., 20081; Kos and Ariya, $2008^{2}$ ). They demonstrate that chemical products resulting from this heterogeneous chemistry could be emitted in the air, modifying atmospheric chemistry (Ariya et al., $2008^{1}$ ).

On the other hand, PBA can be modified by chemical and physical processes in the atmosphere. In this paper, we discuss the atmospheric effects and feedbacks of microbiological and chemical interactions of PBA. Section 2. outlines the abundance of PBA in atmospheric aerosols and clouds. Section 3 illustrates how airborne micro-organisms can influence cloud chemistry and multiphase processes. Section 4 investigates the influence of atmospheric chemistry on the viability of airborne micro-organisms and other PBA properties. Finally, Sect. 5 gives an outlook on research perspectives and suggestions for future field, laboratory and modeling studies.

\section{Sources and abundance of primary biological aerosols in atmospheric aerosols and clouds}

PBA alone or attached to other materials are, by definition, directly emitted from the biosphere to the atmosphere. Pollen $(>10 \mu \mathrm{m})$, bacteria $(\sim 1 \mu \mathrm{m})$, fungal, algae, moss and fern spores $(\sim 10 \mu \mathrm{m})$, viruses $(<0.1 \mu \mathrm{m})$ and fragments of animals and plants constitute PBA (Matthias-Maser and Jaenicke, 1995, 2000; Artaxo and Hansson, 1995; Bauer et al., 2005; Després et al., 2007; Georgakopoulos et al., 2008). PBA components, which are composed of fragments of biological particles (pollen, bacteria, carbohydrates, proteins, waxes, biopolymers, ions) can be found on other types of

\footnotetext{
${ }^{1}$ Ariya, P. A., Domine, F., Kos, G., Amyot, M., Cote, V., Vali, H., Lauzier, T., Legagneux, L., Kuhs, W. F., Techmer, K., Heinrichs, T., Mortazavi, R., Bottenheim, J.: Snow: A Photo-Bio-Chemical Exchange Platform with the Atmosphere, Environ. Res. Lett., submitted, 2008.

${ }^{2}$ Kos, G. and Ariya, P. A.: Identification of wide range of bioorganic and organic volatile compounds in snow at various Arctic and SubArctic sites, J. Geophys. Res., in review, 2008.
}

aerosol particles such as sea spray, dust etc. (Kellogg and Griffin, 2006). Large PBA such as pollen, fern spores and large fungal spores belong to the coarse mode of air particle matter, whereas small fungal spores, small fragments of animal and plants, bacteria, viruses are found in intermediate and fine fractions of aerosol particles (Taylor et al., 2004; Zhang and Anastasio, 2003; Franze et al., 2005). The number and variety of PBA at a specific site are highly variable, and are dependent on several factors. The most important one is the seasonal variability with an increase of the PBA number concentration during the warm period (Di Gorgio et al., 1996; Katial et al., 1997). A diurnal cycle is also observed with a maximum around midday (Lighthart, 1999). Finally, the type of air mass is also clearly a crucial factor; for instance, more bacteria are observed to be carried by urban-influenced air masses than rural and coastal ones (Mancinelli and Shulls, 1978; Shaffer and Lighthart, 1997). Recent investigations suggest that PBA are a major fraction of atmospheric aerosols with roughly $1000 \mathrm{Tg} \mathrm{yr}^{-1}$ emitted compared to $3300 \mathrm{Tg} \mathrm{yr}^{-1}$ for sea salt and $2000 \mathrm{Tg} \mathrm{yr}^{-1}$ for mineral dust (Jaenicke, 2005).

Several studies have shown that fungal spores account for a major fraction of PBA, with characteristic number and mass concentrations on the order of $10^{4} \mathrm{~m}^{-3}$ and $1 \mu \mathrm{g} \mathrm{m}^{-3}$ in continental boundary layer air (Bauer et al., 2008a; Elbert et al., 2007; and references therein). Recent investigations by Bauer et al. (2008b) demonstrate that fungal spores contributed to 10 and $4 \%$ of $\mathrm{OC}$ and to 5 and $2 \%$ of $\mathrm{PM}_{10}$ (particles measuring $10 \mu \mathrm{m}$ or less) in aerosols collected at a suburban and an urban site in Vienna (Austria) from April to July. Based on the average concentrations of spores and molecular tracers, a global emission rate on the order of $17 \mathrm{Tg} \mathrm{yr}^{-1}$, has been estimated for actively wet discharged spores from Basidiomycota, which is one of the major groups of fungi in the biosphere. The global average atmospheric abundance and emission rate of total fungal spores, including wet and dry discharged species, are estimated to be higher by a factor of about three, i.e. on the order of $50 \mathrm{Tg} \mathrm{yr}^{-1}$ (Elbert et al., 2007). Winiwarter et al. (2008) derived an emission factor of $18 \mathrm{~kg} \mathrm{~km}^{-2} \mathrm{yr}^{-1}$ for fungal spores in Europe. Comparisons with estimated rates of emission and formation of other major types of organic aerosol $\left(47 \mathrm{Tg} \mathrm{yr}^{-1}\right.$ of anthropogenic primary organic aerosol; $12-70 \mathrm{Tg} \mathrm{yr}^{-1}$ of secondary organic aerosol) indicate that emissions from fungi should be taken into account as a significant global source of organic aerosol. The effects of fungal spores and related chemical components might be particularly important in tropical regions, where both physicochemical processes in the atmosphere and biological activity at the Earth's surface are particularly intense, and where the abundance of fungal spores and related chemical compounds are typically higher than in extra-tropical regions.

Several studies have found biopolymers like cellulose and proteins (molecular mass $g g 1 \mathrm{kDa}$ ) and other compounds with relatively high molecular mass $(g g 100 \mathrm{Da})$ such as 
humic-like substances (HULIS) (analogous to humic substances in soil, surface water and groundwater) in air particulate matter as well as in fog, cloud, and rain water (Zappoli et al., 1999; Puxbaum and Tenze-Kunit, 2003; Pöschl, 2005; Graber and Rudich, 2006; Sanchez-Ochoa et al., 2007; Ivleva et al., 2007). For Europe the emission of cellulose is estimated at $3 \mathrm{~kg} \mathrm{~km}^{-2} \mathrm{yr}^{-1}$ (Winiwarter et al., 2008). Indeed, biopolymers and other PBA components are likely to account for a large proportion of OC. Proteins, amino acids, and related amino compounds were found to account for up to $\sim 10 \%$ of fine particulate matter and to influence the microstructure and water uptake of aerosol particles (Saxena and Hildemann, 1996; Miguel et al., 1999; Zhang and Anastasio, 2001, 2003; Mace et al., 2003a, 2003b, 2003c; Mikhailov et al. 2004; Kuznetsova et al., 2005; Matsumoto and Uematsu, 2005; Pöschl, 2005; McFiggans et al., 2006; Hock et al., 2008). In the atmosphere, they undergo chemical reactions such as oxidation, nitration, photolysis and hydrolysis, which can modify their optical, chemical and biological properties and eventually result in the formation of HULIS. However, the current understanding of aerosol transformations and the interaction of gases with particles is very limited since they involve multiple physico-chemical processes such as mass transport, phase transition and chemical reactions at the interface or in the bulk of the different compartments: gas, liquid and solid phases (Pöschl, 2005; Fuzzi et al., 2006; Pöschl et al., 2007; see Sect. 4).

Bauer et al. (2002) showed that average mass concentrations of bacteria only amounted to $0.01 \%$ of OC in cloud water, snow, rain and aerosol samples. But, although the mass concentrations of bacteria seem low compared to other organic aerosols, their numbers range from $\sim 10^{3}$ to $\sim 10^{5}$ cells $\mathrm{mL}^{-1}$ (Sattler et al., 2001; Bauer et al., 2002; Amato et al., 2005, Casareto et al., 2006). Bacterial concentrations in cloud water seem to depend mainly on the altitude and location of sampling. Sattler et al. (2001) estimated the average number of bacteria in cloud water to be $\sim 1.5 \times 10^{3} \mathrm{~mL}^{-1}$ at Mt Sonnblick (3106 m a.s.1., Austria) during spring 1997. At Mt Rax (1644 ma.s.l., Austria) during spring 1999 and 2000, the average number of bacteria in cloud water was about $2.0 \times 10^{4}$ cells $\mathrm{mL}^{-1}$ with an air equivalent concentration estimated to be $5.9 \times 10^{3}$ cells $\mathrm{m}^{-3}$ (Bauer et al., 2002). Amato et al. (2005) performing experiments at the Puy de Dôme Mountain (1465 m a.s.l., France) measured $10^{5}$ cells $\mathrm{mL}^{-1}$ in cloud water corresponding to $3 \times 10^{4}$ cells $\mathrm{m}^{-3}$ of cloud volume. Fuzzi et al. (1997), analyzing fog droplets sampled in the Pô Valley, identified three bacterial genera among the culturable fraction (Pseudomonas, Bacillus and Acinetobacter). Amato et al. (2005, 2007a) and Després et al. (2007) observed more diversified culturable populations consisting of many bacterial genera, distributed among various phyla or sub-phyla $(\alpha-, \beta$ - and $\gamma$-Proteobacteria, Bacteroidetes, Actinobacteria and Firmicutes), as well as an important diversity among the culturable fungal and yeast populations. Some isolates present high

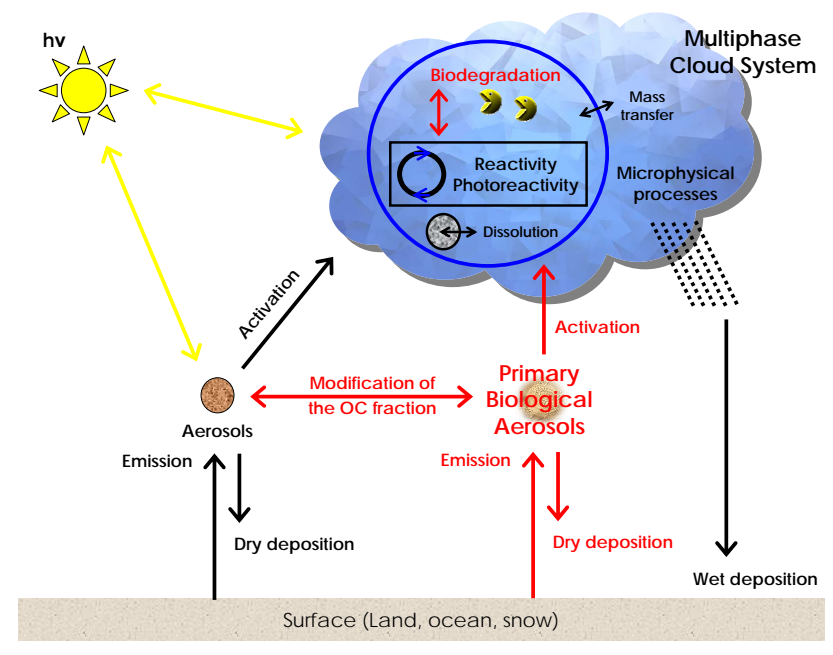

Fig. 1. Schematic representation of the effects of PBA (in red) on atmospheric chemistry.

genetic similarities with strains isolated from cold regions and aquatic environments as well as with plant pathogens.

\section{Influence of airborne micro-organisms on cloud chemistry and multiphase processes}

Airborne micro-organisms have a potential role in cloud chemistry as illustrated in Fig. 1. They can be activated into cloud droplets (Möhler et al., 2007) and consume chemical compounds in the aqueous phase, thereby competing with photochemistry and multiphase processes (dissolution, reactivity, scavenging and deposition). Chemical reactions in the liquid phase modify the amount of radicals which drive the oxidizing power of the atmosphere. For example, iron in aerosols plays a major role in the concentration of radicals in cloud droplets (Deguillaume et al., 2005). As many organic compounds are complexing agents with an iron metal centre, the organo-metallic chemistry can be important in controlling the amount of radicals in clouds (Deguillaume et al., 2005; Parazols et al., 2006). During the lifetime of a cloud, cloud chemistry leads to the formation of new chemical species with relatively low volatility such as inorganic and organic acids, which can modify the physico-chemical properties of aerosol particles (Hegg, 2001) and lead to the formation of secondary organic aerosols (Gelencsér and Varga, 2005). Once the cloud droplet has evaporated, the resulting aerosol particle presents a different chemical composition compared to the initial CCN. It tends to be even more hygroscopic and, thus, more likely to take part in the formation of a new cloud droplet (Feingold and Kreidenweis, 2002).

Several studies have discussed the potential role of living PBA in modifying the multiphase chemistry of the atmosphere via metabolic activity, by using labelled and 
non-labelled chemical species as nutrients (Ariya et al., 2002; Amato et al., 2005; Fuzzi et al., 2006; Amato et al., 2007c). Airborne micro-organisms interact with nitrogen, sulfur and organic compounds in cloud water. Therefore, they potentially modify organic chemistry which is currently subject to high uncertainties. Organic compounds directly or indirectly interact with the aqueous chemistry of radicals, non metal and metal ions and oxidant pools (Ervens et al., 2003; Tilgner et al., 2005; Deguillaume et al., 2005). Organic chemistry inside clouds may consequently modify the chemical budget of both aqueous and gaseous phases (Herrmann et al., 2005). Finally, organic oxidation inside clouds can also be a potentially important source of Secondary Organic Aerosols (SOA) in the atmosphere after the evaporation of cloud droplets (Blando et Turpin, 2000; Ervens et al., 2004; Carlton et al., 2006). In particular, recent studies show that chemical reactivity in cloud droplets leads to the formation of dicarboxylic acids (DCA), such as oxalic acid which are commonly found in the particulate phase in the atmosphere (Ervens et al., 2004; Sorooshian et al., 2006). DCAs dominate in atmospheric cloud water representing between $10 \%$ and more than $70 \%$ of the total dissolved organic carbon (Marinoni et al., 2004).

Airborne micro-organisms are incorporated into cloud droplets and raindrops by nucleation scavenging as they have CCN or IN potential (e.g., Lee et al., 2002; Bauer et al., 2003; Möhler et al., 2007) or by washout processes. Some investigations clearly show that most of these micro-organisms are able to develop at low temperatures (between -5 and $5^{\circ} \mathrm{C}$ ) encountered in clouds. Furthermore, measurements of concentrations of adenosine triphosphate (ATP) in cloud water indicate that most micro-organisms are still metabolically active (Amato et al., 2007d). Moreover, metabolic pathways involving micro-organisms can show some similarities with chemical reactions common to atmospheric radical chemistry as described below. However, the nature and the extent of such processes at molecular levels still have to be evaluated. Furthermore, biodegradation processes are expected to be sensitive to atmospheric conditions. The following discussion will focus on bacteria and fungi and on their potential influence on the chemistry of the atmosphere for which some studies are now available.

Herlihy et al. (1967) first studied the degradation of formic and acetic acid by bacteria in rainwater. Ariya et al. (2002) observed evidence for chemical reactions induced by PBA in solutions containing DCA. They observed that several of the DCA detected in the atmosphere can efficiently be degraded by airborne bacteria and fungi. Estimated degradation lifetimes (few days) are also comparable to major atmospheric oxidants $\left(\mathrm{OH}, \mathrm{O}_{3}\right.$ and $\left.\mathrm{HO}_{2}\right)$ but highly variable as a function of environmental conditions. They also found that the observed microbiological transformation varied as a function of the organic acid used and of the type of PBA. They analysed products of the reaction mixture which are non- or only slightly toxic compounds (acetamide, butanoic and propionic acids, etc.) as well as highly toxic and carcinogenic ones (kojic acid, aflatoxin B1). The isotopic ${ }^{13} \mathrm{C}$ NMR studies clearly demonstrated that airborne microbes can metabolise and chemically transform the DCA to other organic compounds. During these biodegradation processes, molecules can be transformed to more volatile compounds rendering the products available for recycling back into the atmosphere and also to more toxic/pathogenic chemicals. Amato et al. (2005) show that bacterial strains present in cloud water (Puy de Dôme Mountain) contain the enzymatic equipment required for the degradation of some atmospheric compounds. Cloud water was collected by a single-stage cloud impactor (Kruisz et al., 1993) over two hours of sampling for various cloud events. These bulk samples are representative of the bacterial community of the cloud system. In their more recent work (Amato et al., 2007c), they present an overview of the capacities of isolates from cloud water to transform numerous atmospheric compounds. From this study based on 60 microbial strains, they established that, depending on atmospheric conditions, the microbial component is likely to be a sink for carboxylic acids like acetate, formate, lactate and succinate, and also of methanol and formaldehyde. They also can represent a source, for example through the transformation of succinate into fumarate, and of lactate into pyruvate. All those compounds can be found in relatively large concentrations in cloud water (Puxbaum et al., 1988; Grosjean et al., 1989; Granby et al., 1997; Suzuki et al., 1998; Löflund et al., 2002; Marinoni et al., 2004; Van Pinxteren et al., 2005). Their results also indicate preferential metabolic routes for some microbial groups. For instance, Staphylococcus spp. are specialized in the transformation of $\mathrm{C}_{1}$ compounds. This means that depending on the communities present in a given cloud, microbial participation in chemistry would be different. The authors suggest that the genus Pseudomonas would be a good model for further investigations, as this would represent an upper estimate of what can be expected, in terms of chemical impact, from microbes being active in cloud water. Figure 2 adapted from Amato (2006) illustrates the similarities between the radical chemistry within clouds and observed metabolic ways of bacteria collected in cloud water. The degradation of carboxylic acids leads to a final release of $\mathrm{CO}_{2}$ with similar active intermediate molecules. Preliminary studies of Amato et al. $\left(2008^{3}\right)$ address the kinetics of photochemical degradation vs. biodegradation of organic compounds. Their results show that during night-time conditions, the biodegradation rates for organic compounds are in the same order of magnitude as chemical degradation rates driven by $\mathrm{NO}_{3}$ oxidation. During daytime conditions, their calculations suggest that abiotic chemistry driven by the $\mathrm{OH}$ radical is faster than

\footnotetext{
${ }^{3}$ Amato, P., Sancelme, M., Laj, P., and Delort, A.-M.: Is oxidation of organic compounds in clouds by micro-organisms an alternative route to radical chemistry?, Appl. Environ. Microb., submitted, 2008.
} 
biodegradation. It has to be noted that the degradation speeds (abiotic and biotic) are evaluated for ideal conditions and are different than for a complex mixture.

This preliminary result indicates that common radical chemistry considered in a numerical cloud model could compete with kinetic biological degradation as already shown by Ariya et al. (2002), but as they noted, there are substantial differences in the microbiological activity for different environmental conditions, and thus the direct observation without adjustments to relevant environmental conditions (such as $\mathrm{T}, \mathrm{pH}$, irradiation, nutrients and other existing chemicals) can not yield meaningful conclusions. Therefore, the contribution of biodegradation processes has to be evaluated in a cloud system where microphysical processes, photochemical reactivity, dissolution processes and biodegradation will compete and modify the general chemistry of the troposphere.

\section{Influence of atmospheric chemistry on the viability of airborne micro-organisms and other PBA properties}

For microbial cells, the atmosphere is a very stressful environment (Jones and Harrison, 2004; Adhikari et al., 2006). Low temperature is considered to be an important limiting factor for cell activity in the atmosphere and brutal shifts in temperature can stop metabolic activity. However, it has been demonstrated that bacterial activity can occur at subzero temperatures (Christner et al., 2003; Junge et al., 2004) notably due to several physiological processes such as increase in membrane fluidity (Graumann and Marahiel, 1996; Seshu Kumar et al., 2002) and the presence of enzymes active at low temperature (Groudieva et al., 2004). Microbes are shown to be capable of adopting several survival mechanisms; for instance, becoming dormant, changing size and forming spores (Price and Sowers, 2004). In cold temperatures they can adapt by reducing their cell size and the thickness of their capsular polysaccharide, by changing their fatty acid and phospholipids composition, or through energy releasing catalytic redox reactions in ice or in permafrost thereby leading to the creation of habitable microenvironments in ice crystals (Thomas and Dieckmann, 2002; Kos and Ariya, 2008 ${ }^{2}$ ).

In addition to temperature, other environmental limiting factors for cell activity in the atmosphere exist. The atmosphere is a very oxidative medium (e.g., $\mathrm{OH}$ and $\mathrm{HO}_{2} / \mathrm{O}_{2}^{-}$ radicals and ozone) which can oxidise cellular material and damage DNA. Cells have at their disposition enzymes (superoxidase, peroxydases etc.) which reduce or trap radicals such as $\beta$-carotene (Gourmelon et al., 1994; Ochsner et al., 2000). When nutrient concentrations (organic matter essentially) are not sufficient, the global cell metabolism can be reduced and cell development can be stopped. During cell division, irradiation, especially UV, can cause significant damage such as mutation of DNA which can lead to cell death (Sommagura et al., 1997). In response to this stressor, bacteria
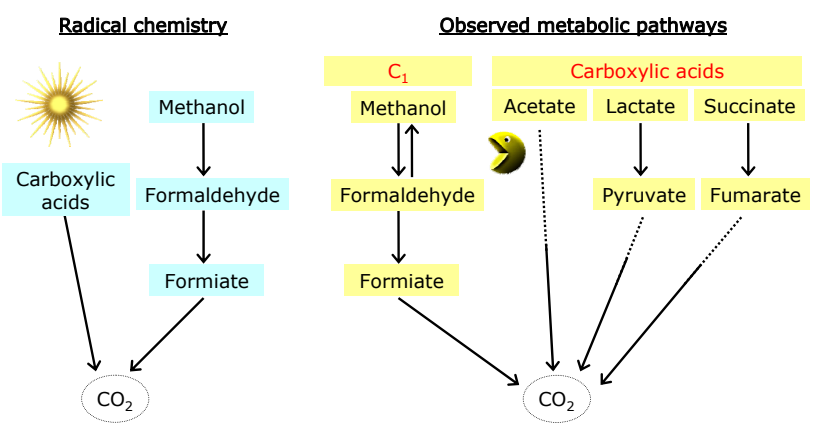

Fig. 2. Transformations of organic compounds by photochemical pathways (on the left side) and by biochemical pathways (on the right side) observed in the laboratory for organic compounds with one carbon atom and for carboxylic acids (adapted from Amato, 2006).

can also produce a diverse suite of pigments (scytonemins, carotenoids, phycobiliproteins, chlorophylls etc.) that absorb from the near UV-B to red wavelengths (Mueller et al., 2005). Sensitivity to irradiation strongly depends on the type of strains and also on altitude since intensity of the UV radiation increases with the altitude.

Airborne micro-organisms in the atmosphere can suffer from dehydration and desiccation leading to the modification of vital structure and ultimately to death (Zentner, 1966). Cell aggregation can diminish sensitivity to desiccation as cells in aggregates protect each other. When incorporated into cloud or fog droplets, microbial cells would not suffer from desiccation and would be transported over greater distances than under clear sky conditions. Thus, clouds and fog represent relatively favourable environments for airborne micro-organisms thereby sustaining their activity and viability. Consequently, fog and clouds represent media in which microbial cells can potentially divide as proposed by Dimmick et al. (1979), Fuzzi et al. (1997), Sattler et al. (2001), Bauer et al. (2002), Amato et al. (2007a, 2007d).

In the atmospheric aqueous phase, the $\mathrm{pH}$ is a crucial parameter (Ariya et al., 2002) for cell viability, partially as cells have to adjust progressively to an acidic medium (Koutsoumanis and Sofos, 2004). The effect of $\mathrm{pH}$ is also linked to other parameters such as oxygenation; hence, the responses to oxidative and acidic stress are similar. The concentration of micro-organisms and the chemical composition of cloud water are clearly correlated. Recent investigations led by Amato et al. (2007d) show that the number of microorganisms in cloud water increases with increasing oceanic contribution and decreases with increasing anthropogenic influence. It suggests that micro-organisms originating from the ocean are preferably integrated in cloud droplets compared to those from continental sources. They also suggest that an eventual multiplication of cells in cloud droplets can be disturbed due to the toxicity of certain polluted clouds. 
Apart from the viability of micro-organisms, multiphase chemical reactions in the atmosphere can also have influences on the effects of PBA on climate and public health. For example, protein molecules can be efficiently nitrated in polluted urban air under summer smog conditions or in mixtures of $\mathrm{NO}_{2}$ and $\mathrm{O}_{3}$ (Franze et al., 2005). The nitration reaction leads to the formation of 3-nitrotyrosine residues in the polypeptide chain of the protein molecule, i.e. to the introduction of an $\mathrm{NO}_{2}$ group next to the $\mathrm{OH}$ group on the phenyl ring of the aromatic amino acid tyrosine (2-amino3-(4-hydroxyphenyl)-propanoic acid). This posttranslational modification of proteins is likely to trigger immune reactions and provides a molecular rationale for the promotion of allergies by traffic-related air pollution, which is confirmed by recent and ongoing biomedical investigations (Gruijthuijsen et al., 2006).

Nitration and other chemical modifications may not only influence the biological properties (allergenicity, toxicity, viability) of PBA. Chemical transformations can also influence the PBA physico-chemical properties which determine their effects on climate (optical parameters; hygroscopicity, surfactant activity, and CCN activity; crystallinity and INA (Ice Nucleation Active) activity). For example, nitration renders colourless proteins yellow (nitrotyrosine acts as a chromophore) thereby potentially modifying reflectivity of PBA. It may also change the molecular and crystalline structures of proteins which serve as active sites for ice nucleation on INA bacteria. The amino acid sequence at the water binding site on the bacterial IFN active protein contains tyrosine. Folding of the protein leading to the formation of $\beta$-sheets occurs at the gly-tyr-gly site in the amino acid sequence in the octapeptide repeated zone of this protein (Gazit, 2002). Formation of 3-nitrotyrosine residues as described above might reduce the water-binding capacity of this site or disrupt the protein tertiary structure necessary for INA.

\section{Research perspectives and suggestions for future studies}

Current knowledge regarding the relationship between atmospheric chemistry and PBA is not very advanced. PBA chemistry and the reciprocal influence of environmental conditions on PBA with regard to the effect on the atmosphere are very complex subjects at the early stages of their development. This young scientific issue gives rise to many questions.

Firstly, regarding the influence of PBA in dry air, the major uncertainty concerns the modification of the physicochemical properties of aerosols: (1) To what extent does the modification of the chemical composition of organic aerosols due to contact/collision with PBA along with particle size and density significantly increase their CCN efficiency ?; (2) Do biopolymers present on carbonaceous aerosols undergo heterogeneous chemistry leading to possible formation of macromolecules such as HULIS substances?
Secondly, recent studies have clearly demonstrated that viable airborne micro-organisms present in the atmosphere can contribute to atmospheric chemistry through degradation processes, as well as chemical change due to the release or desorption of molecules from microbiological entities (Cote et al., 2008). Clouds, fog and rain seem to represent media where the biological activity is significant due to the protection offered from desiccation. Airborne micro-organisms present in fog and clouds use chemical compounds in the aqueous solution as nutrients and therefore perturb the radical chemistry of clouds.

Different approaches are available for studying the effect of PBA on atmospheric chemistry. Laboratory studies allow the characterization of (bio)chemical degradation processes at a given temperature and/or at a given pressure for a given chemical species. In-situ measurements aim at better understanding the chemical processes within clouds through biological, chemical, microphysical, and meteorological measurements and complement laboratory studies in providing more general information on the environmental conditions. These two steps are essential in order to compile data on both bio-chemical processes and quantification of PBA in the atmosphere. Based upon this database, process models are then good tools to assess the relative importance of biological processes vs. chemical ones, while transport models allow the study of various reaction pathways, complex interactions between biological, microphysical, chemical, radiative, and dynamic processes in the framework of the whole cloud system. Then, models are also helpful in running sensitivity tests to study the influence of environmental parameters on multiphase chemistry. These approaches need to be used and developed in synergy in order to quantify the effect of airborne micro-organisms within the frame of atmospheric chemistry:

(1) Further fundamental laboratory chemical-biological research is mandatory to provide answers concerning the PBA monitoring techniques and the kinetics and mechanisms of (bio)chemical transformation involving enzymatic and non-enzymatic processes.

Firstly, many future laboratory investigations are needed for improving the characterization of PBA in the atmosphere. Most of the techniques for monitoring PBA are offline and highly labour intensive (for example, cultivation, staining, fluorescence and electron microscopy, enzyme and immunoassays, DNA analysis etc.) (Maron et al., 2005). New challenging techniques such as aerosol mass spectroscopy (Noble et al., 2000; van Wuijckhuijse et al., 2005; Kleefsman et al., 2007) or aerodynamic sizing and fluorescence spectroscopy (Ho, 2002) allow online monitoring of PBA but still improvements in capturing detailed chemical characteristics at sufficient detection limits are needed. An important point is the effort of the community to compare the different measurements techniques to obtain a comprehensive database. 
Secondly, further studies should also focus on improving our understanding of the kinetics of biological and chemical processes. Laboratory studies are needed to determine the kinetics and mechanisms of the chemical reactions involving organics and molecules such as nitrogenous compounds and trace metals that can potentially interact with airborne micro-organisms. Micro-organism strains isolated in the aqueous phase of clouds need to be selectively isolated or identified in terms of their ability to degrade chemical compounds as well as their ability to be active under extreme conditions (bacteria with pigments, psychrotrophic bacteria, spore-discharging micro-organisms etc.). The degradation ability of these strains will be followed in the laboratory with the objective of determining kinetic constants which will be incorporated in numerical models. The enzymatic activity of micro-organisms also has to be evaluated as a function of numerous factors such as $\mathrm{pH}$, concentrations of oxidizing agents $\left(\mathrm{H}_{2} \mathrm{O}_{2}\right.$, iron $)$ and actinic flux. Therefore, parameterization of the relationships between these sensitive parameters and the metabolic activity of airborne micro-organisms has to be developed.

(2) As mentioned before, the biological activities of airborne micro-organisms are very dependent on environmental conditions. Long-term and detailed observations of the microbial communities (total number, characterization of strains, metabolic activity etc.) are necessary to evaluate the diurnal and seasonal variations of structure and activity of cells as a function of environmental conditions such as humidity, light, temperature etc. Moreover, this climatology of the population of micro-organisms needs to be correlated with the chemical characterization of the sampled air mass. More specifically, in atmospheric water, similar longterm observations need to be performed in order to characterize the living microbial biota as a function of encountered physico-chemical conditions. The laboratory investigations detailed above combined with these in-situ measurements of chemical composition of water will provide a real overall picture of the capacity of micro-organisms to develop under the nutritional conditions offered by atmospheric water.

(3) Finally, modelling will allow us to evaluate the relative contribution of PBA to the chemistry and physics of the atmosphere, and their possible impact on climate. A complete treatment of this interaction requires a rather complex model concerning cloud microphysics (cloud droplets activation, ice activation and multiplication), cloud chemistry, tropospheric chemistry including transport, etc, involving the representation of different scales. For instance, cloud microphysics and chemistry are treated locally in a cloud while tropospheric chemistry and transport will be addressed by the way of 3-D meso-scale simulations. A possible approach to consider the effect of micro-organisms on atmospheric chemistry, modelling could be the following:

(a) Numerical process models describing multiphase cloud chemistry need to consider biological processes in order to evaluate the role of micro-organisms in cloud chemistry.
Even though theoretical, models allow us to study - within the cloud system - the chemical pathways, the complex interactions between microphysics, chemistry and dynamics (i.e. transport) and the influence of environmental parameters on cloud chemistry. At the same time, the structure of numerical models offers the possibility to perform sensitivity analysis on uncertain parameters. Biological degradation processes have to be implemented in models in order to compare explicit photochemistry with biological degradation processes. The whole complexity of biological processes including all the metabolic pathways cannot be implemented in these models. The objective will be rather to evaluate the global potential of micro-organisms present in cloud water on the degradation of relevant chemical compounds. Laboratory studies, as indicated above, need to develop biodegradation parameterizations as a function of environmental conditions. Finally, simulations of various cloud events under different environmental conditions will allow us to generalize the effect of airborne micro-organisms on cloud chemistry.

(b) Sensitivity analysis performed with process models will allow development of parameterizations of the biological degradation of chemical compounds under specific environmental conditions. In the long-term, to consider PBA in more complex 3-D models, they will be considered as one category of aerosol particles and kinetic constants of biological degradation will be introduced as a function of environmental conditions. These formulations will be first implemented in regional models such as the RAMS model (Cotton et al., 2003) or the Meso-NH model (Lafore et al., 1998) and afterwards in more global models such as the MOCAGE model (Josse et al., 2004) or the ECHAM5/MESSy1 model (Tost et al., 2007).

These past 15-20 years have produced a real boost in our knowledge regarding detailed chemistry occurring in the atmosphere. Recent investigations, summarized here, demonstrate that we also need to combine biological processes with classical chemistry. Diverse competences will need to be brought together to examine this interplay between PBA and atmospheric chemical processes. These competences will represent a very broad spectrum of chemical and biological sciences including microbiology, agronomy, atmospheric chemistry, meteorology and modelling. Furthermore, because of the few scientists currently interested in this field and the wide range of competence needed, international and interdisciplinary collaboration is essential.

Acknowledgements. The authors want to greatly acknowledge the European Science Foundation (ESF) for funding for the Exploratory Workshop entitled "Microbiological Meteorology: working at the intersection of biology, physics and meteorology to understand and regulate the microbial component of weather". This meeting held at the "Institut National de la Recherche Agronomique" (INRA) in Avignon (France) has provided a basis for the collaborations that allowed the realization of this paper.

Edited by: C. Slomp 


\section{References}

Acker, K., Mertes, S., Moller, D., Wieprecht, W., Auel, R., and Kalasz, D.: Case study of cloud physical and chemical processes in low clouds at Mt Brocken, Atmos. Res., 64, 41-51, 2002.

Adhikari, A., Reponen, T., Grinshpun, S. A., Martuzevicius, D., and LeMasters, G.: Correlation of ambient inhalable bioaerosols with particulate matter and ozone: a two-year study, Environ. Pollut., 140, 16-28, 2006.

Amato, P., Ménager, M., Sancelme, M., Laj, P., Mailhot, G., and Delort, A-M.: Microbial population in cloud water the Puy de Dôme: implications for the chemistry of clouds, Atmos. Environ., 39, 4143-4153, 2005.

Amato, P.: Les communautés microbiennes de l'eau des nuages : implication dans la chimie atmosphérique, Thèse de Doctorat, Blaise Pascal University, Clermont-Ferrand-France, 2006.

Amato, P., Parazols, M., Sancelme, M., Laj, P., Mailhot, G., and Delort, A.-M.: Micro-organisms isolated from the water phase of tropospheric clouds at the Puy de Dôme: major groups and growth abilities at low temperatures, FEMS Microbiol. Ecol., 59(2), 242-254, 2007a.

Amato, P., Hennebelle, R., Magand, O., Sancelme, M., Delort, A.M., Barbante, C., Boutron, C., and Ferrari, C.: Bacterial characterization of the snow cover at Spitzberg, Svalbard, FEMS Microbiol. Ecol., 59(2), 255-264, 2007b.

Amato P., Demeer F., Melaouhi A., Martin-Biesse A-S., Sancelme M., Laj P. and Delort A-M. A fate for organic acids, formaldehyde and methanol in cloud water: their biotransformation by micro-organisms, Atmos. Chem. Phys., 7, 4159-4169, 2007c, http://www.atmos-chem-phys.net/7/4159/2007/.

Amato, P., Parazols, M., Sancelme, M., Mailhot, G., Laj, P., and Delort, A.-M.: An important oceanic source of micro-organisms for cloud water at the puy de Dôme (France), Atmos. Environ., 41, 8253-8263, 2007d.

Artaxo, P. and Hansson, H. C.: Size distribution of biogenic aerosol particles from the Amazon Basin, Atmos. Environ., 29, 93-402, 1995.

Ariya, P. A., Nepotchatykh, O., Ignatova, O., and Amyot, M.: Microbiological degradation of atmospheric organic compounds, Geophys. Res. Lett., 29, 22, 2077-2080, 2002.

Ariya, P. A., and Amyot, M.: New directions: the role of bioaerosols in atmospheric chemistry and physics, Atmos. Environ., 38, 1231-1232, 2004.

Bauer, H., Kasper-Giebl, A., Loflund, M., Giebl, H., Hitenberger, R., Zibuschka, F., and Puxbaum, H.: The contribution of bacteria and fungal spores to the organic carbon content of cloud water, precipitation and aerosols, Atmos. Res., 64, 109-119, 2002.

Bauer, H., Giebl, H., Hitzenberger, R., Kasper-Giebl, A., Reischl, G., Zibuschka, F., and Puxbaum, H.: Airborne bacteria as cloud condensation nuclei, J. Geophys. Res., 108(D21), 4658, doi:10.1029/2003JD003545, 2003.

Bauer, H., Weinke, G., Scheller, L., Berger, A., Kasper-Giebel, A., Puxbaum, H., Vermeylen, R., Claeys, M., and Maenhaut, W.: Contribution of bioaerosols to organic carbon in urban-fringe aerosols, European Aerosol Conference, Ghent, Belgium, 2005.

Bauer, H., Claeys, M., Vermeylen, R., Schueller, E., Weinke, G., Berger, A., and Puxbaum, H.: Arabitol and mannitol as tracers for the quantification of airborne fungal spores, Atmos. Environ., 42(3), 588-593, 2008a.
Bauer, H., Schueller, E., Weinke, G., Berger, A., Hitzenberger, R., Marr, I. L., and Puxbaum, H.: Significant contributions of fungal spores to the organic carbon and to the aerosol mass balance of the urban atmospheric aerosol, Atmos. Environ., 42(22), 55425549, 2008b.

Blando, J. D. and Turpin, B. J.: Secondary organic aerosol formation in cloud and fog droplets: a literature evaluation of plausibility, Atmos. Environ., 34, 1623-1632, 2000.

Carlton, A. G., Lim, H.-J., Altieri, K., et al.: Link between Isoprene and Secondary Organic Aerosol (SOA): Pyruvic acid oxidation yields low volatility organic acids in clouds, Geophys. Res. Lett., 33, L06822, doi:10.1029/2005GL025374, 2006.

Casareto, B. E., Suzuki, Y., Okada, K, and Morita, M.: Biological microparticles in rain water, Geophys. Res. Lett., 23, 2, 173-176, 2006.

Chin, M. and Wine, P. H.: A temperature-dependent competitive kinetics study of the aqueous-phase reactions of $\mathrm{OH}$ radicals with formate, formic acid, acetate, acetic acid and hydrated formaldeheyde, in: Aquatic and Surface Photochemistry, edited by: Helz, G. R., Zepp, R. G., and Crosby, D. G., Lewis Publishers, Boca Raton, 85-96, 1994.

Christner, B. C., Mosley-Thompson, E., Thompson, L. G., and Reeve, J. N.: Bacterial recovery from ancient glacial ice, Environ. Microbiol., 5, 433-436, 2003.

Cote, G., Kos, R., Mortazavi, P., and Ariya, P. A.: Microbial and "de novo" Transformation of Dicarboxylic Acids by Three Airborne Fungi, Sci. Total Environ., 340, 530-537, 2008.

Deguillaume, L., Leriche, M., Desboeufs, K., Mailhot, G., George, C., and Chaumerliac, N.: Transition Metals in Atmospheric Liquid Phases: Sources, Reactivity, and Sensitive Parameters, Chem. Rev., 105(9), 3388-3431, 2005.

Després, V., Nowoisky, J., Klose, M., Conrad, R., Andreae, M. O., and Poschl, U.: Molecular 15 genetics and diversity of primary biogenic aerosol particles in urban, rural, and high-alpineair, Biogeosciences, 4, 1127-1141, 2007, http://www.biogeosciences.net/4/1127/2007/.

Di Giorgio, C., Krempff, A., Guiraud, H., Binder, P., Tiret, C., and Dumenil, G.: Atmospheric pollution by airborne microorganisms in the city of Marseilles, Atmos. Environ., 30, 155160, 1996.

Dimmick, R. L., Wolochow, H., and Chatigny, M. A.: Evidence that bacteria can form new cells in airborne particles, Appl. Environ. Microbiol. 37, 924-927, 1979.

Donahue, N. M., Robinson, A. L., Stanier, C. O., and Pandis, S. N.: Coupled partitioning, dilution, and chemical aging of semivolatile organics, Environ. Sci. Technol., 40, 2635-2643, 2006.

Edmonds, R. L.: Aerobiology: The ecological systems approach, US-IBP (International Biological Program) Synthesis Series No. 10, 386 pp., 1979.

Elbert, W., Taylor, P. E., Andreae, M. O., and Pöschl, U.: Contribution of fungi to primary biogenic aerosols in the atmosphere: wet and dry discharged spores, carbohydrates, and inorganic ions, Atmos. Chem. Phys., 7, 4569-4588, 2007, http://www.atmos-chem-phys.net/7/4569/2007/.

Elliot, A. J. and McCracken, D. R.: Effect of temperature on $\mathrm{O}^{-}$ reactions and equilibria: A pulse radiolytic study, Radiat. Phys. Chem., 33, 69-74, 1989. 
Ervens, B., George, C., Williams, J. E., Boxton, G. V., Salmon, G. A., Bydder, M., Wilkinsons, F., Dentener, F., Mirabel, P., Wolke, R., and Herrmann, H.: CAPRAM 2.4 (MODAC mechanism): An extended and condensed tropospheric aqueous phase mechanism and its application, J. Geophys. Res., 108, doi:10.1029/2002JD002202, 2003.

Ervens, B., Feingold, G., Frost, G. J., and Kreidenweis, S. M.: A modeling study of aqueous production of dicarboxylic acids: 1 . Chemical pathways and speciated organic mass production, J. Geophys. Res., 109, D15205, doi:10.1029/2003JD004387, 2004.

Exner, M., Herrmann, H., Michel, J.W., and Zellner, R.: Laser pulse initiated measurements of $\mathrm{NO}_{3}$ reactions with $\mathrm{S}(\mathrm{IV})$ and organic compounds in aqueous solutions, in: Proceedings of EUROTRAC Symposium '92: Photo-oxidants: Precursors and Products, 615-618, edited by: Borrell, P. M., Borrell, P., Cvitaš, T., and Seiler, W., SPB Academic Publishing, The Hague, NL, 1993.

Exner, M., Herrmann, H., and Zellner, R.: Rate constants for the reactions of the $\mathrm{NO}_{3}$ radical with $\mathrm{HCOOH} / \mathrm{HCOO}^{-}$and $\mathrm{CH}_{3} \mathrm{COOH} / \mathrm{CH}_{3} \mathrm{COO}^{-}$in aqueous solution between 278 and 328 K, J. Atmos. Chem., 18, 359-378, 1994.

Feingold, G. and Kreidenweis, S. M.: Cloud processing of aerosol as modeled by a large eddy simulation with coupled microphysics and aqueous chemistry, J. Geophys. Res., 107, 4687, doi:10.1029/2002JD002054, 2002.

Franze, T., Weller, M. G., Niessner, R., and Pöschl, U.: Protein nitration by polluted air, Environ. Sci. Technol., 39, 1673-1678, 2005

Fuzzi, S., Mandrioli, P., and Perfetto, A.: Fog droplets - An atmospheric source of secondary biological aerosol particles, Atmos. Environ., 31, 287-290, 1997.

Fuzzi, S., Andreae, M. O., Huebert, B. J., Kulmala, M., Bond, T. C., Boy, M., Doherty, S. J., Guenther, A., Kanakidou, M., Kawamura, K., Kerminen, V.-M., Lohmann, U., Russell, L. M., and Pöschl, U.: Critical assessment of the current state of scientific knowledge, terminology, and research needs concerning the role of organic aerosols in the atmosphere, climate, and global change, Atmos. Chem. Phys., 5, 11 729-11 780, 2006.

Gazit, E.: Global analysis of tandem aromatic octapeptide repeats: The significance of the aromatic-glycine motif, Bioinformatics, $18,880-883,2002$.

Georgakopoulos, D. G., Després, V., Fröhlich-Nowoisky, J., Psenner, R., Ariya, P. A., Pósfai, M., Ahern, H. E., Moffett, B. F., and Hill, T. C. J.: Microbiology and atmospheric processes: biological, physical and chemical characterization of aerosol particles, Biogeosciences Discuss., 5, 1469-1510, 2008, http://www.biogeosciences-discuss.net/5/1469/2008/.

Gelencsér, A. and Varga, Z.: Evaluation of the atmospheric significance of multiphase reactions in atmospheric secondary organic aerosol formation, Atmos. Chem. Phys., 5, 2823-2831, 2005, http://www.atmos-chem-phys.net/5/2823/2005/.

Gourmelon, M., Cillard, J., and Pommepuy, M.: Visible light damage to Escherichia coli in seawater: oxydative stress hypothesis, J. Appl. Bacteriol., 77, 1, 105-112, 1994.

Graber, E. R. and Rudich, Y.: Atmospheric HULIS: How humiclike are they? A comprehensive and critical review, Atmos. Chem. Phys., 6, 729-753, 2006,

http://www.atmos-chem-phys.net/6/729/2006/.
Granby, K., Christensen, C. S., and Lohse, C.: Urban and semirural observations of carboxylic acids and carbonyls, Atmos. Environ., 31, 1403-1415, 1997.

Graumann, P. and Marahiel, M. A.: Some like it cold: response of micro-organisms to cold shock, Arch. Microbiol., 166, 293-300, 1996.

Gregory, P. H.: The microbiology of the atmosphere, Leonard Hill [Books] Ltd., London, New York, xv+251 pp., 1961.

Gregory, P. H.: The Leeuwenhoek Lecture, 1970: Airborne microbes: Their significance and distribution, P. Roy. Soc. B-Biol. Sci., 177, 469-483, 1971.

Griffin, D. W.: Terrestrial micro-organisms at an altitude of $20000 \mathrm{~m}$ in Earth's atmosphere, Aerobiologia, 20, 135-140, 2004.

Grosjean, D.: Organic acids in southern California air: ambient concentrations, mobile source emissions, in situ formation and removal processes, Environ. Sci. Technol., 23, 1506-1514, 1989.

Groudieva T., Kambourova M., Yusef H., Royter M., Grote R., Trinks H., and Antranikian, G.: Diversity and cold-active hydrolytic Bacterial characterization of an Arctic snow cover 9 enzymes of culturable bacteria associated with Artic sea ice, Spitzbergen., Extremophiles, 8, 475-488, 2004.

Gruijthuijsen, Y.K., Grieshuber, I., Stöcklinger, A., Tischler, U., Fehrenbach, T., Weller, M.G., Vogel, L., Vieths, S., Pöschl, U., and Duschl, A.: Nitration Enhances the Allergenic Potential of Proteins, Int. Arch. Allergy Immunol., 141, 265-275, 2006.

Hegg, D. A.: The impact of clouds on aerosol populations, IGAC Activ. Newsl., 23, 3-6, 2001.

Herlihy, L. J., Galloway, J. N., and Mills, A. L.: Bacterial utilization of formic and acetic acid in the rainwater, Atmos. Environ., 21, 2397-2402, 1967.

Herrmann, $\mathrm{H}$. and Zellner, R.: Reactions of $\mathrm{NO}_{3}$-radicals in aqueous solution, in: N-Centered Radicals, edited by: Alfassi, Z. B., Wiley, London, 291-343, 1998.

Herrmann, H., Tilgner, A., Barzaghi, P., Majdik, Z., Gligorovski, S., Poulain, L., and Monod, A.: Towards a more detailed description of tropospheric aqueous phase organic chemistry: CAPRAM 3.0, Atmos. Environ., 39, 4351-4363, 2005.

Ho, J.: Review: Future of biological aerosol detection, Anal. Chim. Acta, 457, 125-148, 2002.

Hock, N., Schneider, J., Borrmann, S., Römpp, A., Moortgat, G., Franze, T., Schauer, C., Pöschl, U., Plass-Dülmer, C., and Berresheim, H.: Rural continental aerosol properties and processes observed during the Hohenpeissenberg Aerosol Characterization Experiment (HAZE2002), Atmos. Chem. Phys., 8, 603-623, 2008, http://www.atmos-chem-phys.net/8/603/2008/.

Ivleva, N. P., McKeon, U., Niessner, R., and Pöschl, U.: Raman microspectroscopic analysis of size-resolved atmospheric aerosol particle samples collected with an ELPI: soot, humic-like substances, and inorganic compounds, Aerosol Sci. Tech., 41, 655671, 2007.

Jacobson, M. C., Hansson, H. C., Noone, K. J., and Charlson, R.J.: Organic atmospheric aerosols: Review and state of the science, Rev. Geophys., 38, 267-294, 2000.

Jaenicke, R.: Abundance of cellular material and proteins in the atmosphere, Science, 308, p. 73, 2005. 
Jones, B. L. and Cookson, J. T.: Natural atmospheric microbial conditions in a typical suburban area, Appl. Environ. Microbiol., 45(3), 919-934, 1983.

Jones, A. M. and Harrison, R. M.: The effects of meteorological factors on atmospheric bioaerosol concentrations - a review, Sci. Total Environ., 326, 151-180, 2004.

Josse, B., Simon, P., and Peuch, V.-H.: Radon global simulations with the multiscale chemistry and transport model MOCAGE, Tellus, 56B, 339-356, 2004.

Junge, K., Eicken, H., and Deming, J. W.: Bacterial activity at -2 to $-20^{\circ} \mathrm{C}$ in Arctic wintertime sea ice, Appl. Environ. Microb., 70, 550-557, 2004.

Kalberer, M., Sax, M., and Samburova, V.: Molecular size evolution of oligomers in organic aerosols collected in urban atmospheres and generated in a smog chamber, Environ. Sci. Technol., 40, 5917-5922, 2006.

Kanakidou, M., Seinfeld, J. H., Pandis, S. N., Barnes, I., Dentener, F. J., Nielsen, C. J., Swietlicki, E., Putaud, J. P., Balkanski, Y., Fuzzi, S., Horth, J., Moortgat, G. K., Winterhalter, R., Myhre, C. E. L., Tsigaridis, K., Viganti, E., Stephanou, E. G., and Wilson, J.: Organic aerosol and global climate modleling: a review, Atmos. Chem. Phys., 5, 1053-1123, 2005, http://www.atmos-chem-phys.net/5/1053/2005/.

Katial, R. K., Zhang, Y., Jones, H. J., and Dyer, P. D.: Atmospheric mold spore counts in relation to meteorological parameters, Int. J. Biometeorol., 41, 17-22, 1997.

Keene, W. C. and Galloway, J. N.: The biogeochemical cycling of formic and acetic acids through the troposphere: an overview of current understanding, Tellus, 40B, 322-334, 1988.

Kellogg, C. A. and Griffin, D. W.: Aerobiology and the global transport of desert dust, Trends Ecol. Evol., 21, 638-644, 2006.

Kleefsman, I., Stowers, M. A., Verheijen, P. J. T., vanWuijckhuijse, A. L., Kientz, C. E., and Marijnissen, J. C. M.: Bioaerosol Analysis by Single Particle Mass Spectrometry, Part. Part. Syst. Char., 24, 85-90, 2007.

Koutsoumanis, K. P. and Sofos, J. N.: Comparative acid stress response of Listeria monocytogenes, Escherichia coli O157:H7 and Salmonella typhimurium after habituation at different $\mathrm{pH}$ conditions, Lett. Appl. Microbiol., 38, 321-326, 2004.

Kruisz, C., Berner, A., and Brantner, B.: A cloud water sampler for high wind speeds, Proceedings of the EUROTRAC Symposium 1992, edited by: Borrell, P. M., SPB Acad., The hague Netherlands, 523-525, 1993.

Kuznetsova, M., Lee, C., and Aller, J.: Characterization of the proteinaceous matter in marine aerosols, Mar. Chem., 96, 359-377, 2005.

Lafore, J. P., Stein, J., Asencio, N., Bougeault, P., Ducrocq, V., Duron, J., Fischer, C., Héreil, P., Mascart, P., Masson, V., Pinty, J. P., Redelsperger, J. L., Richard, E., and Vilá-Guerau de Arellano, J.: The Meso-NH atmospheric simulation system. Part I: adiabatic formulation and control simulations, Ann. Geophys., 16, 90-109, 1998, http://www.ann-geophys.net/16/90/1998/.

Lee, B. U., Kim, S. H., and Kim, S. S.: Hygroscopic growth of E. coli and B. subtilis bioaerosols, J. Aerosol Sci., 33, 1721-1723, 2002.

Lighthart, B.: The ecology of bacteria in the alfresco atmosphere, FEMS Microbiol. Ecol., 23, 263-274, 1997.
Löflund, M., Kasper-Giebl, A., Schuster, B., Giebl, H., Hitzenberger, R., and Puxbaum, H.: Formic, acetic, oxalic, malonic and succinic acid concentrations and their contribution to organic carbon in cloud water, Atmos. Environ., 36(9), 1553-1558, 2002.

Logan, S. R.: Redox reactions of organic radicals with ferrocene/ferricenium species in aqueous solution, I. Radicals derived from carboxylic acids, J. Chem. Soc. Perk. T. 2, 2(7), 751754, 1989.

Lohmann, U. and Feichter, J.: Global indirect aerosol effects: a review, Atmos. Chem. Phys., 5, 715-737, 2005, http://www.atmos-chem-phys.net/5/715/2005/.

Mace, K. A., Duce, R. A., and Tindale, N. W.: Organic nitrogen in rain and aerosol at Cape Grim, Tasmania, Australia, J. Geophys. Res., 108(D11), 4338, doi:10.1029/2002JD003051, 2003a.

Mace, K. A., Kubilay, N., and Duce, R. A.: Organic nitrogen in rain and aerosol in the eastern Mediterranean atmosphere: An association with atmospheric dust, J. Geophys. Res., 108(D10), 4320, doi:10.1029/2002JD003058, 2003b.

Mace, K. A., Artaxo, P., and Duce, R. A.: Water-soluble organic nitrogen in Amazon Basin aerosols during the dry (biomass burning) and wet seasons, J. Geophys. Res., 108(D16), 4512, doi:10.1029/2003JD003557, 2003c.

Mancinelli, R. L. and Shulls, W. A.: Airborne bacteria in an urban environment, Appl. Environ. Microb., 35(6), 1095-1101, 1978.

Marinoni, A., Laj, P., Sellegri, K., and Mailhot, G.: Cloud chemistry at Puy de Dome: variability and relationships with environmental factors, Atmos. Chem. Phys., 4, 715-728, 2004, http://www.atmos-chem-phys.net/4/715/2004/.

Maron, P.-A., Lejon, D. P. H., Carvalho, E., Bizet, K., Lemanceau, P., Ranjard, L., and Mougel, C.: Assessing genetic structure and diversity of airborne bacterial communities by DNA fingerprinting and 16S rDNA clone library, Atmos. Environ., 39, 36873695, 2005.

Matsumoto, K. and Uematsu, M.: Free amino acids in marine aerosols over the western North Pacific Ocean, Atmos. Environ., 39(11), 2163-2170, 2005.

Matthias-Maser, S. and Jaenicke, R.: The size distribution of primary biological aerosol particles with radii $>0.2 \mu \mathrm{m}$ in an urban/rural influenced region, Atmos. Res., 39, 279-286, 1995.

Matthias-Maser S., Bogs, B. and Jeanicke, R.: The size distribution of primary biological aerosol particles in cloud water on the mountain Kleiner Felderg / Taunus (FRG), Atmos. Res., 54, 1$13,2000$.

McFiggans, G., Artaxo, P., Baltensperger, U., Coe, H., Facchini, M. C., Feingold, G., Fuzzi, S., Gysel, M., Laaksonen, A., Lohmann, U., Mentel, T. F., Murphy, D. M., O’Dowd, C. D., Snider, J. R., and Weingartner, E.: The effect of physical and chemical aerosol properties on warm cloud droplet activation, Atmos. Chem. Phys., 6, 2593-2649, 2006,

http://www.atmos-chem-phys.net/6/2593/2006/.

Miguel, A. G., Cass, G. R., Glovsky, M. M., and Weiss, J.: Allergens in paved road dust and airborne particles, Environ. Sci. Technol., 33(23), 4159-4168, 1999.

Mikhailov, E., Vlasenko, S., Niessner, R., and Poschl, U.: Interaction of aerosol particles composed of protein and salts with water vapor: hygroscopic growth and microstructural rearrangement, Atmos. Chem. Phys., 4, 323-350, 2004, http://www.atmos-chem-phys.net/4/323/2004/. 
Möhler, O., DeMott, P. J., Vali, G. and Levin, Z.: Microbiology and atmospheric processes: The role of biological particles in cloud physics, Biogeosciences Discuss., 4, 2559-2591, 2007, http://www.biogeosciences-discuss.net/4/2559/2007/.

Morris, C. E., Sands, D. C., Bardin, M., Jaenicke, R., Vogel, B., Leyronas, C., Ariya, P. A., and Psenner, R.: Microbiology and atmospheric processes: an upcoming era of research on biometeorology, Biogeosciences Discuss., 5, 191-212, 2008, http://www.biogeosciences-discuss.net/5/191/2008/.

Mueller, D. R., Vincent, W. F., Bonilla, S., and Laurion, I.: Extremotrophs, extremophiles and broadband pigmentation strategies in a high arctic ice shelf ecosystem, FEMS Microbiol. Ecol., 53, 73-87, 2005.

Noble, C. A. and Prather, K. A.: Real-Time Single Particle Mass Spectrometry: A Historical Overview of a Quarter Century of the Chemical Analysis of Aerosols, Mass Spectrom. Rev., 19, 248-274, 2000.

Ochsner, U. A., Vasil, M. L., Alsabbagh, E., Parvatiyar, K., and Hassett, J.: Role of the Pseudomonas aeruginosa oxyR-oxyG operon in oxidative stress defense and DNA repair: oxyRdependent regulation of katB-ankB, ahpB, and ahpC-ahpF, J. Bacteriol., 182, 16, 4533-4544, 2000.

Seinfeld, J. H. and Pandis, S. N.: Atmospheric Chemistry and Physics From Air Pollution to Climate Change, John Wiley and Sons, Inc, New York 1998,

Parazols, M., Marinoni, A., Amato, P., Abida, O., Laj, P., and Mailhot, G.: Speciation and role of iron in cloud droplets at the puy de Dôme station, J. Atmos. Chem., 54, 267-281, 2006.

Pöschl, U.: Atmospheric aerosols: composition, transformation, climate and health effects, Angew. Chem. Int. Edit., 2005.

Pöschl, U., Rudich, Y., and Ammann, M.: Kinetic model framework for aerosol and cloud surface chemistry and gas-particle interactions - Part 1: General equations, parameters, and terminology, Atmos. Chem. Phys., 7, 5989-6023, 2007,

http://www.atmos-chem-phys.net/7/5989/2007/.

Price, P. B. and Sowers, T.: Temperature dependence of metabolic rates for microbial growth, maintenance, and survival, P. Natl. Acad. Sci. USA, 101, 4631-4636, 2004.

Prospero, J. M., Blades, E., Mathison, G., and Naidu, R.: Interhemispheric transport of viable fungi and bacteria from Africa to the Caribbean with soil dust, Aerobiologia, 21, 1-19, 2005.

Puxbaum, H., Rosenberg, C., Lanzersorfer, C., Ober, E., and Winwarter, W.: Atmospheric concentrations of formic and acetic acid and related compounds in eastern and northern Austria, Atmos. Environ., 22, 2841-2850, 1988.

Puxbaum, H. and Tenze-Kunit, M.: Size distribution and seasonal variation of atmospheric cellulose, Atmos. Environ., 37(26), 3693-3699, 2003.

Sanchez-Ochoa, A., Kasper-Giebl, A., Puxbaum, H., Gelencser, A., Legrand, M., and Pio, C.: Concentration of atmospheric cellulose: A proxy for plant debris across a west-east transect over Europe, J. Geophys. Res., 112, D23S08, doi: 10.1029/2006JD008180, 2007.

Sattler, B., Puxbaum, H., and Psenner, R.: Bacterial growth in supercooled cloud droplets, Geophys. Res. Let., 28, 239-242, 2001.
Saxena, P., and Hildemann, L. M.: Water-soluble organics in atmospheric particles: A critical review of the literature and application of thermodynamics to identify candidate compounds, J. Atmos. Chem., 24, 57-109, 1996.

Seinfeld, J. H. and Pankow, J. N.: Organic atmospheric particulate material, Annu. Rev. Phys. Chem., 54, 121-140, 2003.

Seshu, K. G., Jagannadham, M. V., and Ray, M. K.: Lowtemperature-induced changes in composition and fluidity of lipopolysaccharides in the Antarctic psychrotrophic bacterium Pseudomonas syringae, J. Bacteriol., 184, 6746-6749, 2002.

Shaffer, B. T. and Lighthart, B.: Survey of culturable airborne bacteria at four diverse locations in Oregon: urban, rural, forest and coastal, Microb. Ecol., 34, 167-177, 1997.

Skidmore, ML, Foght, J.M., and Sharp, M.J.: Microbial life beneath a high Arctic glacier, Appl. Environ. Microbio., 66, 3214-3220, 2000.

Sommagura, R., Obernosterer, I., Herndl, G. J., and Psenner, R.: Inhibitory effect of solar radiation on thymidine and leucine incorporation by freshwater and marine bacterio-plankton, Appl. Environ. Microb., 63, 4178-4184, 1997.

Sorooshian, A., Varutbangkul, V., Brechtel, F. J., Ervens, B., Feingold, G., Bahreini, R., Murphy, S. M., Holloway, J. S., Atlas, E. L., Buzorius, G., Jonsson, H., Flagan, R. C., and Seinfeld, J. H.: Oxalic acid in clear and cloudy atmospheres: Analysis of data from International Consortium for Atmospheric Research on Transport and Transformation 2004, J. Geophys. Res., 111, D23S45, doi:10.1029/2005JD006880, 2006.

Sun, J. and Ariya, P. A.: Atmospheric organic and bio-aerosols as cloud condensation nuclei $(\mathrm{CCN})$ : A review, Atmos. Environ., 40, 795-820, 2006.

Suzuki, Y., Imai, S., Kawakami, M., Masuda, K., and Akasaka, K.: Identification and determination of low-molecular weight organic compounds in contaminated fog water using proton nuclear magnetic resonance spectroscopy, B. Environ. Contam. Tox., 60, 355-362, 1998.

Szidat, S., Jenk, T.M., Gäggeler, H.W., Synal, H.-A., Fisseha, R., Baltensperger, U., Kalberer, M., Samburova, V., Wacker, L., Saurer, M., Schwikowski, M., and Hajdas, I.: Source apportionment of aerosols by ${ }^{14} \mathrm{C}$ measurements in different carbonaceous particle fractions, Radiocarbon, 46, 475-484, 2004.

Taylor, P. E., Flagan, R. C., Miguel, A. G., Valenta, R. and Glovsky, M. M.: Birch pollen rupture and the release of aerosols of respirable allergens, Clin. Exp. Allergy, 34, 1591-1596, 2004.

Thomas, D. N. and Dieckmann, G. S.: Sea ice: an introduction to its physics, chemistry, biology, and geology, edited by: Thomas, D. N. and Dieckmann, G. S., Oxford, Blackwell Science, 402 pp., 2002.

Tilgner, A., Majdik, Z., Sehili, A.M., Simmel, M., Wolke, R., and Herrmann, H.: SPACCIM: Simulations of the multiphase chemistry occurring in the FEBUKO hill cap cloud experiments, Atmos. Environ., 39(23-24), 4389-4401, 2005.

Toom-Sauntry, D. and Barrie, L. A.: Chemical composition of snowfall in the high Arctic: 1990-1994, Atmos. Environ., 36, 2683-2693, 2002.

Tost, H., Jöckel, P., Kerkweg, A., Pozzer, A., Sander, R., and Lelieveld, J.: Global cloud and precipitation chemistry and wet deposition: tropospheric model simulations with ECHAM5/MESSy1, Atmos. Chem. Phys., 7, 2733-2757, 2007, http://www.atmos-chem-phys.net/7/2733/2007/. 
Turpin, B. J., Saxena, P., and Andrews, E.: Measuring and simulating particule organics in the atmosphere: problems and prospects, Atmos. Environ., 34, 2983-3013, 2000.

Vali, G.: Ice nucleation - A review, in: Nucleation and Atmospheric Aerosols, edited by: Kulmala, M. and Wagner, P., Pergamon Press, 271-279, 1996.

van Wuijckhuijse, A. L., Stowers, M. A., Kleefsman, W. A., van Baar, B. L. M., Kientz, Ch. E., and Marijnissen, J. C. M.: Matrix-assisted Laser Desorption/Ionisation Aerosol Time-offlight Mass Spectrometry for the Analysis of Bioaerosols: Development of a Fast Detector for Airborne Biological Pathogens, J. Aerosol Sci., 36, 677-687, 2005.

Van Pinxteren, D., Plewka, A., Hofmann, D., Müller, K., Kramberger, H., Svrcina, B., Bächmann, K., Jaeschke, W., Mertes, S., Collett Jr., J. L., and Herrmann, H.: Schmücke hill cap cloud 20 and valley stations aerosol characterisation during FEBUKO (II): organic compounds, Atmos. Environ., 39, 4305-4320, 2005.

Wainwright, M., Wickramasinghe, N. C., Narlikar, J. V., and Rajaratnam, P.: Micro-organisms cultured from stratospheric air samples obtained at $41 \mathrm{~km}$, FEMS Microbiol. Lett., 218, 161$165,2003$.
Winiwarter, W., Bauer, H., Caseiro, A., and Puxbaum, H.: Quantifying emissions of primary biological aerosol particle mass in Europe, Atmos. Environ., doi:10.1016/j.atmosenv.2008.01.037, in press, 2008.

Zappoli, S., Andracchio, A., Fuzzi, S., Facchini, M. C., Gelencsér, A., Kiss, G., Krivacsy, Z., Molnar, A., Mészaros, E., Hansson, H.-C., Rosman, K., and Zebühr, Y.: Inorganic, organic and macromolecular components of fine aerosol in different areas of Europe in relation to their water solubility, Atmos. Environ., 33, 2733-2743, 1999.

Zentner, R. J.: Physical and chemical stresses of aerosolizaton, Bacteriol. Rev., 30(3), 551-557, 1966.

Zhang, Q. and Anastasio, C.: Chemistry of fog waters in California's Central Valley - Part 3: concentrations and speciation of organic and inorganic nitrogen, Atmos. Environ., 35(32), 56295643, 2001.

Zhang, Q. and Anastasio, C.: Free and combined amino compounds in atmospheric fine particles (PM2.5) and fog waters from Northern California, Atmos. Environ., 37(16), 2247-2258, 2003. 